\title{
Miranda
}

Revue pluridisciplinaire du monde anglophone /

Multidisciplinary peer-reviewed journal on the English-

speaking world

$12 \mid 2016$

Mapping gender. Old images ; new figures

\section{Oral History as an Autobiographical Practice}

\section{Penny Summerfield}

\section{OpenEdition}

\section{Journals}

Electronic version

URL: http://journals.openedition.org/miranda/8714

DOI: 10.4000/miranda.8714

ISSN: $2108-6559$

\section{Publisher}

Université Toulouse - Jean Jaurès

\section{Electronic reference}

Penny Summerfield, "Oral History as an Autobiographical Practice", Miranda [Online], 12 | 2016, Online since 01 April 2016, connection on 16 February 2021. URL: http://journals.openedition.org/miranda/ 8714 ; DOI: https://doi.org/10.4000/miranda.8714

This text was automatically generated on 16 February 2021.

\section{$\Theta \Theta \Theta \Theta$}

Miranda is licensed under a Creative Commons Attribution-NonCommercial-NoDerivatives 4.0 International License. 


\title{
Oral History as an Autobiographical Practice
}

\author{
Penny Summerfield
}

1 The American oral historian Ronald Grele defined oral history in 1973 as "the interviewing of eye witness participants in the events of the past for the purposes of historical reconstruction." (Grele [1973] 1996, 63) This sounds like a useful definition, but things have moved on since the 1970s: the field of oral history has expanded; the academic respectability of the method has increased; the uses of oral history have proliferated. Taking Grele's definition phrase by phrase, "interviewing" is certainly what oral historians do, and they typically record their interviews, transcribe them so that there is a written text as well as an audio (and sometimes a video) recording, and archive them so that other researchers can use them. "Historical reconstruction" is still the purpose of oral history, in that historians use oral history interviews as sources from which to interpret and represent the past. The part of Grele's definition which, nearly half a century later, no longer describes the method adequately is the concept of "eye witness participants in the events of the past".

2 At the time Grele was writing, American and British oral historians identified the events or historical phenomena in which they were interested, and sought witnesses to those things. They were preoccupied with the accuracy of the information that interviewees provided and the reliability of memory. The shift that has occurred over the decades is towards greater interest in the narratives people compose about the past and the ways in which memory is socially, culturally and psychically constructed. Oral history today is less a quest for objective eye-witness accounts in which the narrator provides the historian with data for interpretation, and more a means to engage with experience, subjectivity, and historical imagination. The questions British oral historians asked in the 1970s and 80s concerned what interviewees' accounts told us about such aspects of past social life as agricultural practices, schooling, industrial work, strikes and motherhood. These days, while interest in an expanding range of such topics has flourished, oral history has become more methodologically reflexive. Questions now include such issues as how interviewees construct themselves through 
narratives that arise in dialogue with an interviewer, and how personal experience and public histories interact in the production of memory stories. Oral history is widely regarded as an autobiographical practice rather than a social survey technique. As Grele himself put it in 2010, there has been "a shift from concern with data to concern with text". (Grele 2010)

However, while this intellectual refocusing is central to any discussion of the present state of oral history, it is important not to overstate it. One approach did not displace the other; one was not wrong and the other right; they coexist alongside other approaches that have longer roots, such as the use of oral history for the collection of folklore. (Abrams 2010) Oral history is used as a research method in different ways and with varying emphases on "data" and "text" by a wide range of disciplines within academia and by a huge variety of organizations outside, from schools and community groups to voluntary organizations and hospitals.

The ensuing discussion explores these developments within oral history in Britain. The argument is that the practice of oral history has pushed against the constraints imposed by the social science tradition from which it emerged. Understanding subjectivity rather than seeking objectivity has become important, and with it a need to address the interrelationship of culture and memory, in particular the ways in which personal and public accounts of the past feed off each other. Attention to the process of subjective narration has enhanced awareness that narrators undertake a life review when recalling a personal past, and that the narratives they compose may or may not be conducive to personal, psychic composure. The form that a narrative takes contributes to the meanings communicated by the narrator. So, too, does the subject position the narrator allocates to her- or himself. Illustrations are drawn from oral history projects on aspects of the Second World War with which I have been involved.

\section{Recovery history}

5 The purpose of oral history as it developed in Britain from the 1970s was radical. As the founding father of British oral history, Paul Thompson, has written, the main influence was the new social history movement, which challenged the focus of mainstream history on political elites and economic trends. (Thompson 1978) ${ }^{1}$ The oral history movement demanded a reorientation of history, ending the neglect of the ordinary person by insisting that if records did not exist they would have to be created with the help of the new technology of the portable tape recorder. The objective was to recover histories that would otherwise be lost, hence the term "recovery history". This approach was enthusiastically taken up by historians of social and political movements, by feminist historians, and by historians of members of ethnic minorities. The histories recovered in this way included: the social conditions of ordinary people before the First World War (Thompson 1975); stories of participation in the Spanish Civil War of 1936-39 (Fraser 1979); children's experiences in the Edwardian classroom (Humphries 1981); the history of working-class women in industrial Lancashire (Roberts 1984); and the contribution of West Indian women to the British war effort (Bousquet and Douglas 1991), to give just five examples. The radical intention was to give a voice to the voiceless, to raise consciousness, and to empower those for whom there was now a place in written history. 
Oral historians had to fight for recognition of the method, however. Criticisms included the accusation that oral history was unreliable because of the fallibility of memory, and that it was invalid because the people interviewed were not representative of the wider population. On the first of these, the distinguished radical historian Eric Hobsbawm decried oral history on the grounds that memory could not be a reliable medium for historical research. (Hobsbawm 206) Defenders of oral history responded that all memory is not unreliable all the time. Thus Trevor Lummis argued that while shortterm memory declines with age, so that it becomes difficult to remember what happened yesterday, long-term memory often improves. (Lummis Chapter 11) Paul Thompson added that the reliability of memory varies with the types of things remembered: specific dates and public events are often hard to remember; oftenrepeated routines and incidents of personal importance are recalled even at a vast distance in time. (Thompson 1978) In any case, argued the early defenders of oral history, oral sources do not have a monopoly of such problems; written sources bear the scars of partiality, inaccuracy, special pleading, and, frequently, physical disintegration.

7 As far as representativeness is concerned, the social science traditions in which oral history developed emphasized the importance of the representative sample as the basis for generalization from data. In the 1970s, oral historians such as Paul Thompson, who undertook a large-scale project on Edwardian working lives, and Elizabeth Roberts, who researched the lives of working-class women in Lancashire from the 1880 s to 1940s, strove for representativeness. However well-intentioned, such endeavours faced major difficulties, relating to the sample and the questionnaire. It is not possible to obtain a statistically representative sample of any population in the past. If one wanted to interview a representative sample of the workers at a particular factory in 1940, for example, one would be confronted firstly by the complications of collecting data on the social profile of all the workers at that time, and then by the difficulties of tracing those who fitted the sampling criteria, many of whom would have moved or changed their names, and by the demographic problem of differential survival rates since 1940. Even supposing a sample could have been identified, there would still be the difficulty of the researcher's dependence on the willingness of those whom it was possible to track down, not just to answer questions, but to delve into personal memory and weave what they found there into narrative form. This is linked to the other major problem, the questionnaire. Oral history is dialogic: it is the product of a dialogue between the interviewer and interviewee, a conversation in which the oral historian encourages the interviewee to compose memory stories about themselves in the past. The structured interview based on a standard questionnaire is not appropriate for the oral history interview. Even though oral historians typically take a schedule of questions to an interview, they ask follow-up questions and prompt their interviewees to elaborate and explain what they mean. Different interviewees understand the same questions in different ways and the answers vary in length, complexity and ambiguity, meaning that the responses are not directly comparable. The interest of the interviewer in a particular subject, about which they know something and want to find out more, is constantly modified by the preoccupations of the interviewee with aspects of the past that are unknown to the interviewer. The dialogue can facilitate discoveries on both sides. 
Discovery, and changing the historical agenda, are at the heart of oral history. Interviewees often remember things that surprise their interviewers, and sometimes surprise themselves. Oral historians test the validity of such evidence less to cast doubt on whether their respondents are telling the truth, than to find out whether this is an opportunity to revise the historical record. This is done by seeking alternative sources, either similar, such as other oral interviewees, or different, such as documentary evidence, to corroborate testimonies. Putting questions derived from oral history to other primary sources frequently brings to light evidence that has been overlooked or distrusted because it was unexpected. This can be illustrated by a project I undertook on the Home Guard in Britain in the Second World War (Leverhulme Trust 1999-2000.) The Home Guard was a volunteer, part-time, military force, recruited in the summer of 1940 to defend Britain against the threat of invasion and form the basis of resistance in the event of occupation. Members of the Home Guard worked at their usual civilian jobs during the day, and trained and went on military manoeuvres in the evenings and at weekends. Since the Second World War it has been widely assumed that Home Guards were all men, an assumption underpinned by an official wartime ban on women joining the force. An announcement in the press in 1941 stated, "The training of women as unofficial Home Guards has not been authorized. Weapons and ammunition in the charge of the Army or of Home Guards must not be used for the instruction of women." (The Times, 12 November 1941)

However, oral history provides evidence that British women joined the Home Guard, and were taught to use weapons, in spite of the official ban. Kathleen Holmes, for example, a switchboard operator at the Post Office living in East London, remembered joining the force and that "the Home Guard were quite tough on us" when training the women to use the heavy Lee Enfield rifle: "we used to disarm and put them together and then lay on our tummies and shoot, and we, you know, it was really, you did get quite an impact on your shoulder from them, but, we did that all the time, and then we learnt how to handle hand grenades." (Holmes interview 483) ${ }^{2}$ Further research in the archives, as well as interviews with both women and men, unearthed more evidence of women's active presence in the Home Guard. (Summerfield and Peniston-Bird 2007.) Oral history enables us to recover such "lost" aspects of history, and to ask historiographical and theoretical questions about why that element has been played down in, or omitted from, published histories. Oral history as recovery history is valuable and important not only for giving a voice to the voiceless, but also for challenging historical knowledge.

10 The value of oral history derives both from evidence of, and information about, what happened to people in the past (which as we have seen is often not recoverable by other means), and also from the way in which interviewees remember and express their experience. Thus it goes beyond the idea that its aim is to record the accounts of "eye witness participants in the events of the past," to return to Grele. The telling of experience is, according to post-structural theorists Joan W Scott and Judith Butler, the means by which subjects constitute themselves. (Scott 1991; Butler 1990) Subjectivity is constructed through the language of the interchange in an oral history interview. Rather than seeing the subjectivity of oral history as a problem for the collection of objective "data," oral historians have come to see oral history as providing a special opportunity for the exploration of the historical subject. Recognising that oral history 
is about subjectivity demands attention to at least two further issues: the relationship of culture to memory and the dynamics of the interview.

\section{Culture, memory, and the "cultural circuit"}

11 Valuable though it is, there have been criticisms of the use of oral history for recovery purposes. Oral historians who enthusiastically embrace the opportunity to rescue neglected aspects of the past from obscurity are seen as naïvely regarding their interviewees' narratives as windows on the past. They try to establish the reliability of the narrator by undertaking corroborative research, but then treat the account of experience as unmediated and "authentic," overlooking the workings of memory and recall. Scholars argue that memory interacts with subsequent experience, and with ideological and cultural representations of both the present and the past, so that accounts of the past are never pure recall of life as it was. Further, as Joan W. Scott has pointed out, accounts of experience cannot give direct access to social reality, because it is impossible to remember outside the language and discourses in which we make sense of our lives. (Scott 1991)

Many accounts of the past are imbued with nostalgia, that is a longing for a time assumed to be better than the present. In oral histories of British experience in the Second World War, this is often expressed through comparisons between the supposed unselfish community spirit of wartime and the greedy individualism of the present. Several of the men interviewed for the home defence project put this clearly. For example, Ray Atkins, who joined a Home Guard unit in Manchester at the age of sixteen, said that remembering the Home Guard "takes me straight back to the feeling of how things once were in this country ... All of the British population had this feeling of being in it together and backs to the wall and all that. So that if I do think about the Home Guard I think of that feeling I had about, you know, all pulling together, all working together." (Atkins interview 633) Bill Trueman, who had served in the Wiltshire Home Guard, added "unfortunately now we seem to be missing this, and the whole amount of comradeship created then is getting to be something of the past." (Trueman correspondence 76) The ideal of national unity and all pulling together was urged at the time as part of wartime propaganda and has been a feature of ideological accounts of the war since. Encapsulated in the concept of "the people's war" it has become a paradigm through which to see Britain in the Second World War.

What are oral historians to do with such insights? The close relationship between culture, language and meaning makes it impossible to regard the influence of a public discourse, such as that of "the people's war," as some kind of mould that must be scraped off to reveal the supposedly underlying historical "truths." Should one, then, give up on the radical mission of oral history to recover the past of neglected groups, and study only the cultural constructs that seem to get in the way of revealing experience as it was lived? Or should we focus on what memories tell us about the present, through a study of the "way in which popular memories are constructed and reconstructed as part of a contemporary consciousness"? (Johnson 1982, 219) Both are possibilities, but both take the focus away from the original mission of oral history, to claim a place for the ordinary individual in history.

Another possibility is to accept that discourses inevitably and continuously shape consciousness and behaviour, and to acknowledge that oral history taps memory that is 
mediated by this means. The mediation is as much a part of the history under scrutiny as the memory. The versions of the past communicated through family traditions and community cultures, as well as through education, religion, politics, and a wide variety of public media, influence the ways in which individuals remember and interpret their personal histories. They are historical phenomena, which the historian can study, not only as such, but also in their inter-relation with memory and recall. The Italian oral historians Luisa Passerini and Alessandro Portelli stress the interaction of ideology and collective memory within personal accounts. Passerini's special contribution was to identify silences in the memories of members of the Italian labour movement about the years of fascist dictatorship in the 1920s and 1930s: their accounts leapt from pre-1922 to the years of resistance between 1943 and 1945. Her conclusion was that her interviewees had unconsciously buried the years between, when their agency was undermined and their lives were compromised by the dominant fascist ideology, which had been all but expunged from collective memory.

Other oral historians, including myself, have stressed the possibilities of exploring both sides of the relationship between popular culture and personal memory. (Summerfield 2004) For example, it is possible both to study the construction and promotion of the discourse of the people's war, characterized by the notion of wartime unity and community spirit, and to probe this idea with interviewees, eliciting specific, personal memories that contradict, as well as supporting, it. Thus members of the Home Guard, including those who spoke nostalgically of national unity and emphasized the togetherness of the Home Guard, also referred in the course of lengthy interviews to contradictory experiences of status, class and gender tensions in wartime: between office clerks and manual workers; between men from different regions; between townand country-dwellers; between husbands and wives; and over the appointment of wealthy locals as Home Guard officers regardless of their competence.

Important to this endeavour is the idea of the "cultural circuit." According to this concept, developed by Graham Dawson and applied to oral history by Alistair Thomson and others, locally-told, individual life stories are picked up, developed and portrayed in a generalised form in public media constitutive of popular culture, such as films, television, fiction, and newspaper articles. As a result, the meaning of experiences of, for example, the Second World War becomes crystallised in popular and general accounts of "the War" (as it is persistently referred to in the British context). Individuals narrating their own accounts subsequently use elements of this generalised form in recalling their personal part in that war, and indeed find it difficult to speak outside it.

The project on home defence in the Second World War provides a case in point. The Home Guard was the subject of a powerful and pervasive popular representation in a BBC television comedy series, "Dad's Army," about a fictional seaside Home Guard unit led by the local bank manager, Captain Mainwaring. It satirized the incompetence of the part-time volunteer soldiers of the force while affectionately depicting the earnestness of the majority as well as the bolshiness and insouciance of the few. "Dad's Army" was itself based partly on the personal memories of one of the script-writers, Jimmy Perry, augmented by numerous other recollections including some sent in by viewers of the first series. Perry and his collaborator David Croft selected and embroidered what they hoped were the funniest stories, crafting them into the format of a half-hour sitcom. (See Summerfield and Peniston-Bird 2007) The success of the 
series, broadcast in eighty episodes from 1968 to 1977, with numerous repeats to this day, gives it considerable purchase on the popular imagination.

Men and women interviewed for the project spontaneously referred to "Dad's Army" and many used it as a touchstone for their recollections. Gwen Taylor, for example, an office worker who joined the Home Guard in South Manchester in 1942, said that her Home Guard captain "was very much ex-First World War army, he was a very, very military man, he was Captain Ginger ... and he looked all the world like a little round Captain Mainwaring ... He was very self-important, he used to bristle, you know." (Taylor interview 14) She and others went on to compare other members of their units with the seven main characters in the sitcom. Several of the male interviewees identified with the youngest recruit in "Dad's Army," Frank Pike, the show's "stupid boy" according to the exasperated Captain Mainwaring. One respondent even signed his introductory letter to the project, "Nigel Grey, Alias Stupid Boy." (Grey correspondence 25)

"Dad's Army" was an important point of reference for interviewees even when they criticized it for misrepresenting the Home Guard. Kaitlin Wells, a seventeen-year-old bank clerk in the autumn of 1940 when she joined the Home Guard, said of "Dad's Army," "I think it was very typical of what went on, you know. All sorts of people involved in it, you know. The opportunist and the patriotic. I think, I don't know, it was reasonably true to life I think." Yet she also said that, in her experience, the Home Guard changed over time and became a well-equipped, well-disciplined and efficient adjunct of the army, a development that was not portrayed in the series. She added some reflections on how the show might have been improved, as a comedy. It would have been even funnier, she suggested, if it had included a women's Home Guard section, like her own; the women could have been used to mock the male Home Guards who, in her experience, were "so ham-handed with trying to use the typewriter and things like that." (Wells interview 179) In fact a single episode of the sitcom did feature women's recruitment to the Home Guard, but they were included solely to develop an unexpectedly romantic side to Captain Mainwaring's character. The message was that the women's contribution was dysfunctional and disruptive and the force was better off without them. The inclusion that Kaitlin suggested would have fed the cultural circuit with a theme that would have challenged the dominant understanding that the Home Guard was an exclusively male organization, would have given comic focus to gendered interactions, and would have lessened the silence within contemporary collective memory over women's participation in the Home Guard.

\section{Life review and personal composure}

Gerontologists such as Peter Coleman and Joanna Bornat suggest that the process of "life review" occurs in reminiscence in old age. This typically involves three features: looking back questioningly to evaluate a life as it was lived; comparisons of the self with other individuals or of the younger with the older self; and the search for selfaffirmation. This kind of life review is central to other types of autobiographical practice too, such as the memoir. In the analysis of oral history interviews there is scope to explore it in order to understand more about the subject and his or her place in history. Historians can deepen and build understanding of an individual by eliciting her subjective assessments of the value of her life, studying the sources of affirmation 
and denial in her account, and noting the continuities and contradictions in her comparisons with others and with her younger self.

An example comes from an interview undertaken as part of another project on Britain during the Second World War, this time focusing on women's working lives. (Economic and Social Research Council, 1990-92) Sadie Bartlett, a twenty-one year old hairdresser living in Norfolk in 1943, joined the Timber Corps, a branch of the Women's Land Army. This was an organization set up to supply female labour to all branches of agriculture, which were being depleted of young men by recruitment to the armed forces and were under pressure to increase production due to shortages of food and raw materials in Britain at war. The women of the Timber Corps worked not on farms but in remote forests, felling trees, preparing them for transportation, and loading them onto lorries to go to the mines and factories where they were used for war production. Even though not part of the Armed Forces, this agricultural organisation used military terminology ("Timber Corps," "Land Army") and issued its members with uniforms. (Summerfield 1998) In the interview with Sadie Bartlett, following a relaxed discussion of the items that constituted the uniform (hats, berets, coats, jodhpurs, linen shirts, woolen pullovers, socks and desperately uncomfortable boots), the interviewer (i/v) asked Sadie (SB) whether the women of the Timber Corps "had to wear the uniform in the evenings." In response Sadie told the following story:

SB. Oh yes, well if not you weren't allowed anywhere you see. You got away with a lot with the uniform on. It was safer for one thing. If you were hitch-hiking or anything like that, you know. I had one man once, he said to me, he stopped, and I said, "Oh what have you stopped for? Were you going to ask for a cigarette?" So he said, "No, you know what I want." [pause] So I said, "Is that all you picked me up for?" So he says, "Yes." So I says, "Right mate! I'm stronger than you. You look a bit weedy! [laughter] But one thing, you've got to get my trousers off first and that's rather difficult! You've got to undress me. I don't mind, if you want to try, I'll come off best." [pause] "Oh," he said. So anyway, he said "Oh well, that's that." He got in the cab and drove off. It was in the middle of the night, I do remember that. So anyway there was a five-barred gate, so I sat on the five-barred gate, had a cigarette. I could see in the distance a signal box and I thought "Oh well, nobody ever comes along this road, I'll make my way to the signal box!" I wasn't worried or anything. I wasn't - you know, it don't seem possible, does it? I'd be scared stiff now if I was left on a country road! Anyway I suppose I finished my cigarette and sat there for a little while and he came back again. So I said, "Oh, are you going to try your luck now?" "Oh no," he said. "No, I'm going to take you where you want to go." I was going to Market Harborough actually. So I said, "Oh, alright, as long as you promise not to start anything." "No," he said. "No, it'll be alright, come on." So he took me to Market Harborough and that was that. But you had a lot of things like that and actually your uniform was, as I say, an insurance.

i/v. Protection

SB. Protection, yes, yes. (Bartlett interview 152)

This is a story of a common wartime practice, hitch-hiking, which was a cheap and easy way to get around when there was both relatively little traffic on the road and plenty of goodwill among drivers especially towards anyone in uniform. It is also a story of another common but less well recognized, and countervailing, occurrence: the sexual threat men presented to women. British nostalgia for "the people's war" in which, as we have seen, the population was supposedly united across divisions of social class, region, age, ethnicity, and gender in order to mount effective collective defense, has meant that the persistence of sexual exploitation in wartime has been underplayed in published histories. Sadie's testimony thus has a "recovery" role beyond the value of 
her account of her working life in the Timber Corps. In addition, we can hear Sadie reflecting on her younger self in this extract; a self in a body physically strengthened by wartime work and protected by a "masculine" wartime uniform, with a mental resilience to match ("you've got to get my trousers off first, and that's rather difficult!"). The memory of the confidence of that younger self ("I wasn't worried or anything"), startles the narrator herself because, as a woman in her seventies, she feels so different from the way she was then ("It don't seem possible, does it? I'd be scared stiff now"). The extract provides an example of the kinds of reflections that characterized Sadie's life review (and that recurred in other parts of the interview), concerning her former physical strength, her phlegmatic approach to life's challenges, and the empowerment that she derived from war service. Even though Sadie did not express her war story in heroic terms, it is evident (in part from the chuckles that punctuate what could have been a terrifying tale of sexual menace) that recalling and narrating such episodes enhanced her self-esteem.

Another way of understanding the dynamics of life review within oral history narratives is through the concept of "composure". This term has been used to indicate a dual process at work in an interview. (Dawson 1994; Thomson 1994; Summerfield 2004) On the one hand it refers to the composition of the narrative that the interviewee tells, and on the other to the achievement of personal composure or psychic equilibrium through the process of telling. These are the vehicles for the construction of subjectivity in an interview.

People composing life stories deploy a variety of narrative genres, such as the fairy tale in which fate governs life, the epic in which life involves overcoming obstacles to reach a desired goal, or the escape story in which life is about evading powerful constraints. As Marie-Françoise Chanfrault-Duchet argues, the genre itself provides clues about how the narrator sees herself in relation to social structures and processes, as well as about the cultural constructs at her disposal. Often the narrator's strategy is to combine several genres: parts of a life may be told as an epic struggle in which the narrator is the protagonist, while in other parts fate or luck rule the life story. Usage depends on the aspect of their lives that narrators are talking about as well as the way they are interpreting this part of their life story.

Many narrators use an anecdotal method of narration in which short snapshots are strung together to form an account. "Anecdotal" evidence tends to be dismissed in social science as unrepresentative and unreliable. However, attention to the anecdote as a narrative form reclaims its place in research. An anecdote is usually complete in itself; it is told vividly with humour or irony; and it frequently ends with a punch-line or final reflection emphasising the intended meaning. Sadie Bartlett's anecdote about her experience while hitch-hiking, reviewed above, illustrates all these features. The denouement, that is the return of the potential harasser, subdued, meek, and ready to drive Sadie to her desired destination, is capped off by Sadie's reprise of the topic of uniform, which was the initial prompt for the story, and which provides the punch-line that sums up the meaning of the episode: "your uniform was, as I say, an insurance." In the interview as a whole, Sadie used an anecdotal narrative form for relating specific events in which she constructed her subjectivity in particular ways, combined with a more generalized and descriptive method of talking about family, work and post-war life. In both, Sadie depicted herself as subject to forces more powerful than herself that inflicted injustices and near disasters. As in the hitch-hiking story, her wartime self 
found the strength to assert itself against them when required. However, in her narrative, her post-war self was less able to do so, indicative of both the empowerment of women like herself in wartime and their subordination in the years that followed.

Some interviewees compose narratives that consist almost entirely of anecdotes. One such was Kaitlin Wells, interviewed for the project about the Home Guard in the Second World War. Asked how she came to join the Home Guard, near the beginning of the interview, Kaitlin told a story about her father's determination that the women in the family would be able to defend themselves if there was an invasion, a prospect that seemed only too possible in light of the evacuation of the British Expeditionary Force from Dunkirk and the fall of France in the summer of 1940. Kaitlin's father was a former soldier, bank manager, Home Guard captain, and local public figure in the town of Workington, then in Cumberland, on the coast of North-West England. The story focuses on his efforts to teach Kaitlin to shoot, using his service pistol, in the family's tennis court in the back garden of their home in Stainburn outside Workington.

KW. Well anyway, I remember when war was, when the war started, my father had his revolver, from I suppose, I don't know whether it was from India or from the 1418 war, but he had this, was it a Webley? A Webley, big, big revolver with six bullets that go in a valve. He would take me down on the tennis court to shoot at some tin cans, you know. Because, so that my mother and I could defend ourselves if the Germans landed, you know. And we were taking pot shots at these tin cans and of course the terrific bang, you know, when the, when it went off, it was very loud, and somebody rang the police up to report that the Germans had landed, you know! The Germans were attacking in Stainburn, parachutists had arrived, you know. And the next thing we knew was that, I don't know if it was the police or the Army came, and it was very embarrassing really but we were, my father was advised not to do it, you know. But it was funny really when you think about it. (Wells interview 59)

Kaitlin's anecdote is partly about the unusual phenomenon of a young woman learning to shoot in response to the wartime threat of invasion. However the humour focuses on the unintended consequences of this target practice. Not only did it convince a neighbour that the invasion had begun in the remote Cumberland village of Stainburn, but it compromised Kaitlin's father, whose over-enthusiasm to teach his daughter to defend herself led this pillar of the community to receive an official reprimand. The shooting story, as well as Kaitlin's later anecdotes, relate closely to events involving her father and the Workington Home Guard. In this one she is personally involved, a player in his very serious, yet comic, game, but in others she is more unequivocally an observer, able to recall and report meaningful episodes and draw lessons from events and characters of the time, but not the central protagonist. In short, Kaitlin's oral history narrative is that of an "eye witness."

As we have seen, oral historians have moved away from their early quest for "eye witnesses" as the source of "data," towards attention to the text and to subjectivity. Analysis of Kaitlin's interview indicates that narratives composed as the voice of the eye-witness communicate their own meanings about subjectivity. For Kaitlin the important aspects of the war were lodged in her father's world of military experience and public responsibility rather than her own world of humdrum home life, boring clerical work, and stoic coping. At the same time, while she respected and admired her father and the other men of the Home Guard, she spotted their weaknesses and recounted stories that illustrated them with wry humour. Kaitlin's testimony suggests that a narrator's construction of herself in a narrative as an "eye witness" 
communicates how she positions herself in relation not just to the topic of the interview but to the gendered social world in which she has lived.

The first meaning of the term "composure" refers, as we have seen, to the types of narrative an interviewee composes and the meanings they communicate. The second refers to the psychic consequences for the narrator of composing a personal narrative. Charlotte Linde argues that the achievement of integration is a common outcome of telling life stories. The reconstruction of an individual's past in dialogue with an interviewer frequently involves the production of a narrative that puts the pieces of a life together and satisfies the teller. The process facilitates her personal composure, that is, the achievement of psychic equilibrium. Peter Coleman has observed that a strategy of reminiscence particularly oriented towards self-affirmation involves the repetition of stories that are satisfying to the narrator. Kaitlin had written several of the anecdotes that she told in her interview, in the letter by which she responded to the announcement of the project in the press. Her account showed signs of the "composed" quality of a narrative striving for self affirmation.

The discoveries and uncertainties of life review spool dynamically from the interchange in an interview, and at times put composure at risk. While some interviewees experience interviews as an enjoyable "trip down memory lane" through which they can reclaim their past, discovering, like Sadie Bartlett, a youthful self that, in retrospect, they could admire, others are preoccupied with the dangers of losing their past, or are affected by a strong sense of discontinuity. Following a long string of anecdotes, the interviewer asked Kaitlin Wells how it felt to remember the Second World War. Pressed to reflect directly on herself in this way she said, "When I look back on it, it all seems so long ago you know, as though it never really happened, as though it probably happened to somebody else really, more than me." (Wells interview 360) For all that she evidently enjoyed telling stories about the Home Guard, Kaitlin's selfpositioning as an eye-witness did not, ultimately, give her a comfortable sense of coherent identity but of disjuncture, conducive to discomposure.

31 The achievement of "composure" when talking about oneself depends in part on the audience to whom one is speaking. Research on British women's wartime memories indicates that women commonly experience disbelief or dismissal when they speak to family or friends about their wartime experiences. This is especially the case when they recall activities that transgress current gender norms, such as doing heavy or skilled work, or learning to use firearms. The failure of the wider society to appreciate the significance of such aspects of the past, and a process of collective forgetting, contribute to the unreceptiveness of such audiences. The role of women in the Home Guard is a case in point. Half way through the interview Kaitlin Wells asked her interviewer, "What are you going to do with all this information that you're gathering?" and was told that it would be the stuff of talks and publications because so little was known about women's contribution to the Home Guard. Kaitlin's response indicated her experience of this public ignorance, and she confirmed that it was the cause of her own resulting habitual silence about her membership of the Women's Home Guard Auxiliary: "You know, I mean I keep quiet about it because I, I think people would just laugh, you know, and say, 'What was the Home Guard?" (Wells interview 177) The absence of stories about women Home Guards from the dominant public representations of the force predisposed audiences to be unreceptive, which had in 
turn silenced Kaitlin. Oral history gives subjects the opportunity to break such public and self-enforced silences, and hence to overcome the tragedy of losing their pasts.

\section{Conclusion}

The original radical mission of British oral history to recover lost histories and thereby to give ordinary individuals a place in history remains important. Over time, however, oral history usage has itself pushed at the parameters of traditional social science methodology. Treating oral history as an autobiographical practice has refocused scholarly attention on the numerous ways in which an oral narrative is imbued with meaning. The shift towards textual analysis leads us to interrogate the strategies that the narrator uses, as well as the stories she tells, to understand the subjectivity she composes for herself. Rather than constituting the neutral, objective, observer imagined by social scientists of the 1970s, the identity of "eye witness" is in fact one such subject position. The eye-witness may have been what oral historians thought they were looking for in the 1970s, and standing on the margins may indeed enable sharp observation. However, as we have seen in the case of Kaitlin Wells, it can also infuse a degree of alienation or disorientation from the past under discussion, because it is at one remove from the subject herself, and from the process of composing a narrative constitutive of that subjectivity. 'Composure' inevitably involves narrators drawing upon and interacting with the discourses about the past that circulate in the public domain in the search for a way of telling their own story that is satisfying, meaningful and affirming. Far from constituting "contaminations" that need to be eradicated, this swirl of ideas about the past, borne for instance by popular culture, is integral to memory. It needs to be analysed in its own right, as well as in relation to the uses interviewees make of it in framing and recounting their own memories through the process of life review and the search for integration. In short, oral history, seen as an autobiographical practice rather than a social survey technique, not only recovers the past and through doing so challenges historical knowledge. It also expands the meaning of "history."

\section{BIBLIOGRAPHY}

Abrams, Lynn. Oral History Theory. London: Routledge, 2010.

Atkins, Ray (pseudonym). Born 1925. Interview, 23 ${ }^{\text {rd }}$ March 2000.

Bartlett, Sadie (pseudonym). Born 1933. Interview, November 1991.

Bornat, Joanna. "Reminiscence and Oral History: parallel universes or shared endeavor?" in The Oral History Reader. Ed. Robert Perks and Alistair Thomson. London: Routledge, 2006.

Bousquet, Ben, and Colin Douglas. West Indian Women at War: British Racism in World War II. London: Lawrence and Wishart, 1991. 
Butler, Judith. Gender Trouble: Feminism and the Subversion of Identity. London: Routledge, 1990.

Chanfrault-Duchet, Marie-Françoise. "Textualisation of the Self and Gender Identity in the Lifestory" in Feminism and Autobiography: texts, theories, methods. Ed. Tess Cosslett et al. London: Routledge, 2000.

Coleman, Peter. "Creating a Life Story: the task of reconciliation," The Gerontologist 39:2 (1999): 133-9.

Dawson, Graham. Soldier Heroes. British Adventure, Empire and the Imagining of Masculinities. London: Routledge, 1994.

Economic and Social Research Council Grant R000 23 2048, "Gender, Training and Employment 1939-1950." Penny Summerfield. 1990-92.

Fraser, Ronald. Blood of Spain: the experience of civil war, 1936-1939. London: Allen Lane, 1979.

Grele, Ronald. "Directions for Oral history in the U.S." [1973] In Oral History: An Interdisciplinary Anthology. Ed. David K. Dunaway and Willa K. Baum. United States: Altamira Press, 1996.

---. Envelopes of Sound: the art of oral history. Chicago: Precedent Publications, 1975.

---. “The History of Oral History”, Columbia University, 30 June 2010. Accessed 13 September 2014 https://www.youtube.com/watch?v=voPIGiv3sIQ

Grey, Nigel. Born 1924. Correspondence, $17^{\text {th }}$ April 2000.

Hobsbawm, Eric. On History. London: Weidenfeld and Nicolson, 1997.

Holmes, Kathleen. Born 1919. Interview, 25 $5^{\text {th }}$ May 1999.

Humphries, Stephen. Hooligans or Rebels?: oral history of working class childhood and youth, 1889-1939. Oxford: Blackwell, 1981.

Johnson, Richard, et al. Making Histories: Studies in History-writing and Politics. London: Hutchinson, 1982. See especially Chapter 6 "Popular memory: theory, politics, method."

Leverhulme Trust Research Grant F/185/AK "The Gendering of Home Defence in the Second World War." Penny Summerfield. 1999-2000.

Linde, Charlotte. Life Stories: the Creation of Coherence. Oxford: Oxford University Press, 1993.

Lummis, Trevor. Listening to History: the Authenticity of Oral Evidence. London: Hutchinson, 1987.

Passerini, Luisa. Fascism in Popular memory: the cultural experience of the Turin working class.

Translated by Lumley, Robert and Jude Bloomfield. Cambridge: Cambridge University Press, 1987.

Portelli, Alessandro. The Battle of Valle Giulia. Oral History and the Art of Dialogue. Madison, WI: University of Wisconsin Press, 1997.

Roberts, Elizabeth. A Woman's Place: an oral history of working-class women, 1880-1940. Oxford: Blackwell, 1984.

Scott, Joan W. “The Evidence of Experience.” Critical Inquiry 17:4, (1991): 773-797.

Summerfield, Penny. "Culture and Composure: Creating Narratives of the Gendered Self in Oral History Interviews." Cultural and Social History 1:1, (2004): 65-93.

---.. Reconstructing Women's Wartime Lives: Discourse and Subjectivity in Oral Histories of the Second World War. Manchester: Manchester University Press, 1998. 
---. and Corinna Peniston-Bird. Contesting Home Defence: Men, Women and the Home Guard in the Second World War. Manchester: Manchester University Press, 2007.

Taylor, Gwendoline. Born 1924. Interview, $21^{\text {st }}$ February 2000.

The Times, 12 November 1941.

Thompson, Paul. The Edwardians. London: Weidenfeld and Nicolson, 1975.

---. The Voice of the Past. Oxford: Oxford University Press, 1978, 1988, 2000.

Thomson, Alistair. Anzac memories: Living with the Legend. Oxford: Oxford University Press, 1994.

---. "Fifty Years on: an international perspective on oral history." Journal of American History 85:2, (1998): 581-595.

Trueman, Bill. Born 1924. Correspondence, 29 $9^{\text {th }}$ December 1999.

Wells, Kaitlin (pseudonym). Born 1923. Interview, $19^{\text {th }}$ May 2000.

\section{NOTES}

1. In contrast, in the USA the impulsion for oral history began earlier, in the 1950s, and came from projects designed to tap the memories of members of regional elites who had pioneered the development of the nation. See, for example, http://bancroft.berkeley.edu/collections/ roho.html

2. Interviewees were given pseudonyms if they expressed a preference for anonymity when asked at the time of the interview. This is a controversial issue among oral historians, some of whom take the view that anonymity for all is appropriate, since it protects the subject from the interpretations advanced by the historian which neither partner can predict at the time of interview. Others feel that, as far as possible, interviewees should be given their "place in history" by name. The number after the name of an interviewee in the citations refers to the numbered paragraph in the transcript from which the quote is taken.

\section{ABSTRACTS}

Oral history has changed its focus since the 1970s. It is still an important method of recovering neglected histories, but whereas once oral historians aspired to collect objective data from eye witnesses, practitioners now increasingly regard the methodology as an autobiographical practice centred on the subjectivity of the narrator. As the representative sample loosened its grip, the need to understand how subjectivity is constituted in an interview became more urgent. Oral history demanded revision of the historical agenda in the 1970s; the changes in its orientation challenge how history itself is conceptualized. This article explores some of the implications of the shift, drawing on two projects on Britain in the Second World War for illustration.

L'histoire orale a évolué dans ses objectifs depuis les années 1970. Celle-ci garde tout son intérêt dans la restitution d'histoires jusque-là négligées, mais si les premiers pratiquants avaient 
l'ambition d'atteindre l'objectivité censée résulter de témoignages directs, aujourd'hui sa méthodologie est plutôt envisagée en tant que réalisation autobiographique, centrée sur la subjectivité du narrateur. Avec l'abandon progressif d'une approche fondée sur «l'échantillon représentatif ", il est devenu essentiel de mieux comprendre comment la subjectivité se construit au cours d'un entretien. L'histoire orale a ainsi entraîné une révision programmatique de cette histoire pratiquée dans les années 70 et l'orientation nouvelle remet en question la conceptualisation même de l'objet histoire. Cet article examine les implications de ce changement d'optique en s'appuyant sur deux projets qui portent sur la Grande-Bretagne pendant la Deuxième guerre mondiale.

INDEX

Keywords: oral history, subjectivity, narrative, cultural circuit, life review, composure, Second World War, Home Guard, Women's Land Army (WLA), Women's Timber Corps, women's history Mots-clés: histoire orale, subjectivité, narration, circuit culturel, récit de vie, composure, Deuxième guerre mondiale, histoire féminine, défense civile

\section{AUTHORS}

\section{PENNY SUMMERFIELD}

Professor of Modern History

University of Manchester

penny.summerfield@manchester.ac.uk 